\title{
LIENOTOXICITY OF BORDETELLA PERTUSSIS IN MICE
}

\author{
T. IIDA AND T. OKONOGI \\ Central Research Laboratories, Sankyo Co. Ltd, \\ Hiromachi, Shinagawa-ku, Tokyo

\section{Plates VI and VII}

Although many investigations have been made on the pathological changes in lungs of animals after intranasal inoculation of Bordetella pertussis (Burnet and Timmins, 1937; Bradford, 1938), there are only a few reports of the pathological changes produced in animals when these organisms are inoculated by other routes (Ehrich et al., 1942; Yamamoto et al., 1959; Kurokochi, 1961). During a study of pulmonary oedema produced in mice by intranasal inoculation of $B$. pertussis organisms, as observed by Andersen (1957), we observed a marked change in the size and colour of spleens of mice challenged intravenously with a sublethal dose of living phase-1 organisms. The spleens of mice surviving after intravenous injection of some test $B$. pertussis toxin fractions also showed the same changes. An attempt was made to characterise the structural changes involved in this expression of toxicity.

The toxic effect of $B$. pertussis on the mouse spleen is recorded in the present paper, and it is suggested that the organism's dermonecrotic toxin participates in the production of the characteristic structural changes that we describe.

\section{MATERIALS AND METHODS}

Mice. Male 4-wk-old mice of the DDN stock purchased from Gunma Laboratory Animal Co., Gunma, Japan, were used throughout the following experiments.

Cortisone acetate. "Corton" (Nippon Merck-Banyu Pharmaceutical Co., Tokyo) was administered subcutaneously. used.

B. pertussis strains. Phase-1 organisms of the Tohama strain and strain 18-323 were

B. pertussis "toxin". Phase-1 Tohama organisms maintained on Bordet-Gengou medium containing 20 per cent. ox blood were cultivated on semisynthetic charcoal medium (Taguchi, 1958) at $37^{\circ} \mathrm{C}$ for $48 \mathrm{hr}$. A batch of $40 \mathrm{~g}$ (wet weight) of culture was suspended at a concentration of 100-200 mg in $1 \mathrm{ml}$ of distilled water and disintegrated with a sonic oscillator (15 kHz, $250 \mathrm{~W}$; Kubota Co., Japan) for $20 \mathrm{~min}$. while the suspension was cooled with ice-chilled water. After centrifugation of the sonicate at 10,000 r.p.m. for $30 \mathrm{~min}$. to remove particulate material, the soluble products (about $4 \mathrm{~g}$ protein) were fractionated by DEAEcellulose column chromatography by a modification of the method described by Onoue, Kitagawa and Yamamura (1963) as follows.

In an ice-chilled waterbath, $250 \mathrm{ml}$ of the sonicate diluted 1.5 -fold with cold distilled water was added to $50 \mathrm{ml}$ of the suspension of calcium phosphate gel ( $40 \mathrm{~g}$ wet weight) freshly prepared by the method of Meister (1952). The mixture was stirred for $15 \mathrm{~min}$. and then centrifuged at 7500 r.p.m. for $10 \mathrm{~min}$. The precipitated gel was extracted with $90 \mathrm{ml}$ of $0.1 \mathrm{M}$ sodium phosphate buffer $(p \mathrm{H} 8 \cdot 0)$ for $15 \mathrm{~min}$. and centrifuged again to obtain a clear

Received 3 Apr. 1970; accepted 9 June 1970.

J. MED. MICROBIOL.-VOL. 4 (1971) 
extract. A saturated solution of ammonium sulphate was slowly added to the extract to yield a final ammonium sulphate concentration of 31 per cent. The precipitate was collected by centrifugation, dissolved in $10 \mathrm{ml}$ of distilled water and dialysed against $0.001 \mathrm{M}$ sodium phosphate buffer $(p H \mathbf{H} \cdot 4)$ overnight at $4^{\circ} \mathrm{C}$. Then an amount of this crude toxic fraction equivalent to $300 \mathrm{mg}$ protein was applied to a DEAE-cellulose column (Serva, $0.76 \mathrm{~m}$.equiv. per $\mathrm{g} ; 2 \times 23 \mathrm{~cm})$, which had been washed with $0.001 \mathrm{M}$ sodium phosphate buffer $(p \mathrm{H} 7.4)$, and chromatographed by a stepwise elution with successive $300-\mathrm{ml}$ amounts of (i) $0.005 \mathrm{M}$ sodium phosphate buffer $(p H 7.4)$ containing $0.01 \mathrm{M} \mathrm{NaCl}$, (ii) $0.02 \mathrm{M}$ sodium phosphate buffer $(p \mathrm{H} \mathrm{7.4)}$ containing $0.01 \mathrm{M} \mathrm{NaCl}$, and (iii) $0.04 \mathrm{M}$ sodium phosphate buffer $(p \mathrm{H} 7 \cdot 4)$ containing $0.05 \mathrm{M} \mathrm{NaCl}$. The effluent was collected in 4-ml amounts by an automatic fraction-collector at a flow rate of $10 \mathrm{ml}$ per hour in a cold room. Since the toxic activity was predominantly observed in the effluents obtained with the last buffer, these effluents were pooled, precipitated by half saturation with ammonium sulphate and dissolved in a small volume of distilled water; the yield was about $30 \mathrm{mg}$ protein. After dialysis against $0.005 \mathrm{M}$ sodium phosphate

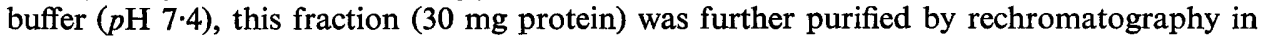
the same way but with a smaller column $(1 \times 19 \mathrm{~cm})$. After reconcentration by half saturation with ammonium sulphate as above, this toxic fraction (now about $5 \mathrm{mg}$ protein) was distributed in small ampoules, frozen and stored at $-80^{\circ} \mathrm{C}$. Two preparations, D-23-II and D-30-I, obtained in this way from different purification experiments, were used.

In the present paper, a dose of the toxin fraction is expressed in terms of the protein content estimated by the Folin test in which bovine plasma albumin was used as a standard. The toxin fraction at a concentration of $500 \mu \mathrm{g}$ protein per $\mathrm{ml}$ in saline showed no detectable reactions with antibacterial rabbit serum, but a few precipitin bands developed against antitoxic rabbit serum when Ouchterlony agar diffusion and immuno-electrophoresis procedures were performed. The antibody titres of both immune sera used are noted below.

Rabbit immune sera. Antitoxic or antibacterial serum was prepared by immunising rabbits with cultures of strain 18-323 as described previously (Sato, 1958; Sato, Tenjin and Iida, 1958). Agglutinin titres of the immune sera against phase-1 organisms were 5120 with antibacterial and antitoxic sera. Antitoxin titres were estimated by lethality tests in mice, skin tests in guinea-pigs and lienotoxicity tests (q.v.) in mice; in these tests, sonicated bacterial cells were used as toxin (see below); when the highest dilution of antitoxin required to neutralise a given dose of toxin was 1 in $x$, the serum was said to have a value of $x$.

Toxicity tests. For estimating a minimal lethal dose (MLD), $0 \cdot 1-\mathrm{ml}$ doses of serial dilutions of toxic material were injected intravenously into groups of five mice and deaths were recorded for 7 days. Survivors were then killed with chloroform and their spleens were weighed. A group of five untreated mice were killed at the same time. The mean of spleen weights per $10 \mathrm{~g}$ body weight was calculated and the toxic effect on the spleen weight was expressed as the ratio of the mean value for the treated groups to the mean value for the controls. From the values thus obtained, the 50 per cent. spleen weight-reducing dose or the 50 per cent. lienotoxicity dose (LTD50) was obtained by a probit method. In the skin tests, a minimal necrotising dose (MND) was determined in terms of the observed effect $24 \mathrm{hr}$ after intradermal injection of the same test material as that used in the lethality tests into the shaved backs of guinea-pigs.

Neutralisation test. Equal volumes of serial dilutions of antitoxic serum were mixed with equal volumes of an appropriate test dose of the sonicate and incubated at $37^{\circ} \mathrm{C}$ for $1 \mathrm{hr}$. Each $0 \cdot 1 \mathrm{ml}$ of the mixture was injected intravenously into mice or intracutaneously into the shaved backs of guinea-pigs.

Histological examination. At various intervals after intravenous injection of the toxin, groups of four mice were killed and the brain, lungs, thymus, liver, spleen, adrenals, kidneys, bone marrow and mesenteric lymph-nodes of each were fixed with 4 per cent. formaldehyde. Paraffin-embedded sections were stained with haematoxylin-eosin and according to Pap's modification of Bielschowsky's method or Mallory's acid fuchsin staining procedure.

Counting of blood leucocytes. Blood samples were collected by cutting tails with sharp scissors; total cell counts were estimated and differential counts were performed on Giemsastained preparations. 


\section{RESULTS}

Activities of the toxin fractions isolated from $B$. pertussis

by column chromatography

The sonicate and two toxic fractions, D-23-II and D-30-I, partially purified from the sonicate by DEAE-cellulose column chromatography, were used as sources of the test toxin in the following experiments and their relative potencies

\section{TABLE I}

The relative lethal, dermonecrotic and lienotoxic potencies of thermolabile factors present in a sonicated preparation of Bordetella pertussis and in two toxic fractions

\begin{tabular}{l|c|c|c}
\hline \multirow{2}{*}{$\begin{array}{c}\text { Materials } \\
\text { tested }\end{array}$} & \multicolumn{2}{|c}{ Number of units of activity as $\mu \mathrm{g}$ protein* when unit of activity was } \\
\cline { 2 - 4 } & $\begin{array}{c}\text { the minimum lethal } \\
\text { dose (MLD) }\end{array}$ & $\begin{array}{c}\text { the minimum } \\
\text { necrotising dose (MND) }\end{array}$ & the LTD50† \\
\hline $\begin{array}{l}\text { Sonicate } \\
\text { Toxin fraction } \\
\text { D-23-II } \\
\text { D-30-I }\end{array}$ & 3.5 & 0.5 & 0.48 \\
\hline
\end{tabular}

* Estimated by the Folin reaction.

$\uparrow$ The dose giving 50 per cent. reduction in spleen weight (see Methods).

TABLE II

The effect of graded doses of B. pertussis sonicate on spleen weights of test mice

\begin{tabular}{|c|c|c|c|}
\hline \multirow{2}{*}{$\begin{array}{c}\text { Dose of } \\
\text { sonicate } \\
(\mu \mathrm{g})\end{array}$} & \multicolumn{3}{|c|}{$\begin{array}{l}\text { Results for spleen weight index (mg)* (with percentage } \\
\text { spleen weight reductiont in brackets) in }\end{array}$} \\
\hline & expt 1 & expt 2 & expt 3 \\
\hline $\begin{array}{l}1.82 \\
0.91 \\
0.46 \\
0.23 \\
0.12 \\
0\end{array}$ & $\begin{array}{l}13(83) \\
22(71) \\
38(49) \\
58(23) \\
53(29) \\
75(0)\end{array}$ & $\begin{array}{l}13(75) \\
20(61) \\
30(41) \\
55(109) \\
47(8) \\
51(0)\end{array}$ & $\begin{array}{c}\ldots \\
\cdots \\
32(46) \\
38(36) \\
45(24) \\
59(0)\end{array}$ \\
\hline
\end{tabular}

* Mean spleen weight per $10 \mathrm{~g}$ body weight of five test mice.

$\dagger$ Percentage reduction of the mean spleen weight of the five test mice compared with that of the five control mice.

were determined in terms of their lethal, dermonecrotic and lienotoxic properties (table I). The neutralising potency of an antitoxic serum was determined with the sonicate as toxin in mouse lethality, guinea-pig dermonecrosis and mouse lienotoxicity tests. The dilutions and the respective challenge doses were 1 in 32 (10 MLD), 1 in 256 (8 MND), and 1 in 800-1600 (10 LTD50). 


\section{Atrophy of mouse spleens after intravenous injection of the B. pertussis toxin}

The relation of the spleen weight loss to the intravenous dose of sonicate or toxic fraction is indicated in tables II and III. The degree of weight loss is

TABLE III

The effect of graded doses of $B$. pertussis toxic fractions given intravenously on spleen weights of the test mice

\begin{tabular}{|c|c|c|c|}
\hline \multirow{2}{*}{$\begin{array}{l}\text { Toxic fraction } \\
\text { tested }\end{array}$} & \multirow{2}{*}{$\begin{array}{l}\text { Dose } \\
(\mu \mathrm{g})\end{array}$} & \multicolumn{2}{|c|}{$\begin{array}{l}\text { Results for spleen weight index (mg)* (with } \\
\text { percentage spleen weight reduction } \dagger \text { in } \\
\text { first brackets) in }\end{array}$} \\
\hline & & expt 1 & expt 2 \\
\hline D-23-II & $\begin{array}{l}1.25 \\
0.63 \\
0 \cdot 31 \\
0 \cdot 16 \\
0.08 \\
0.04 \\
0\end{array}$ & $\begin{array}{c}\ldots \\
\ldots \\
9(89)(2 \mathrm{~s} \ddagger) \\
20(70) \\
43(46) \\
79(0)\end{array}$ & $\begin{array}{c}8(92)(1 \mathrm{~S}) \\
15(86)(3 \mathrm{~S}) \\
19(82) \\
30(71) \\
45(56) \\
73(28) \\
102(0)\end{array}$ \\
\hline D-30-I & $\begin{array}{l}0.5 \\
0 \cdot 25 \\
0 \cdot 13 \\
0.06 \\
0\end{array}$ & $\begin{array}{l}9(85)(3 S) \\
11(82) \\
23(62) \\
36(41) \\
61(0)\end{array}$ & $\begin{array}{l}\cdots \\
\cdots \\
\cdots \\
\cdots\end{array}$ \\
\hline
\end{tabular}

* Mean spleen weight per $10 \mathrm{~g}$ body weight of the survivors of five test mice.

$\dagger$ Percentage reduction of mean spleen weight in relation to that of five control mice.

$¥$ Number of survivors on left of $S$, if $<5$.

expressed as a percentage reduction of the average value of the control group and a 50 per cent. lienotoxicity dose (LTD50) was determined by a probit method with a dose-response curve ranging from 0.01 to $1.00 \mu \mathrm{g}$ of the injected toxin (fig. 1).

The LTD50 values obtained with the sonicate and the toxic fractions were $0.48 \mu \mathrm{g}, 0.07 \mu \mathrm{g}$ (D-23-II), and 0.08 $\mu \mathrm{g}$ (D-30-I) respectively. The spleen weight reduction rate in mice given higher sublethal doses of the toxin deviated from linearity. After subcutaneous injection of the toxin, a similar but less marked response was observed in the mouse spleen; in subcutaneous tests the LTD50 of the toxin fraction D-30-I was $1.53 \mu \mathrm{g}$. However, a subcutaneous haemorrhage at the site of injection was evident at a dose of $0.08 \mu \mathrm{g}$.

After intravenous injection of the toxin D-30-I, the body weight gains were suppressed to a varying extent depending upon the dose of toxin, but the late type of weight loss described by Iwasa et al. $(1966,1968)$ and Ishida (1968) was not noticed. The body weight gains of the test mice are recorded in fig. 2. 
The toxic activity was lost after heating at $56^{\circ} \mathrm{C}$ for $10 \mathrm{~min}$., and intravenous injection of the sonicate thus treated, even in a dose of $50 \mu \mathrm{g}$, did not induce the

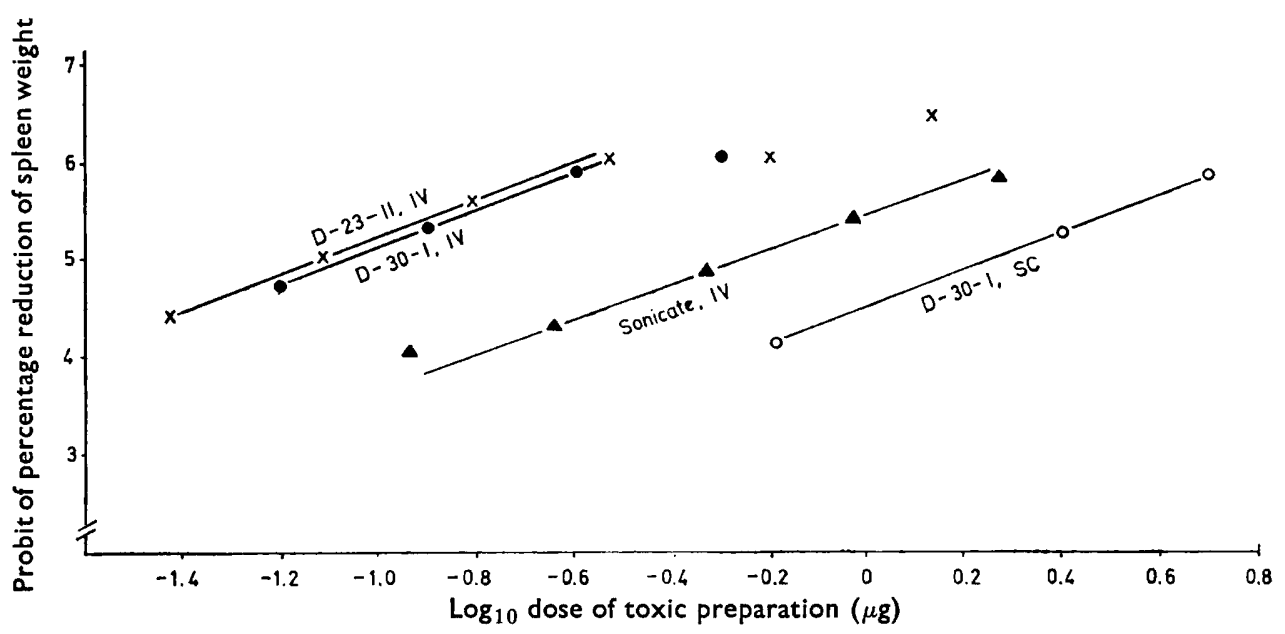

Fig. 1.-The determination by probit method of the relation between the challenge dose of different toxic preparations derived from $B$. pertussis and the percentage reduction of spleen weight of the test mice.

$$
\times-\_=\text {Fraction D-23-II given intravenously; }
$$
venously; $\mathbf{\Delta}-\mathbf{A}=$ sonicate given intravenously; cutaneously. IV = Intravenous; $\mathrm{SC}=$ subcutaneous.

$\longrightarrow=$ fraction D-30-I given intra$\mathrm{O}-\mathrm{O}=$ fraction $\mathrm{D}-30-\mathrm{I}$ given sub-

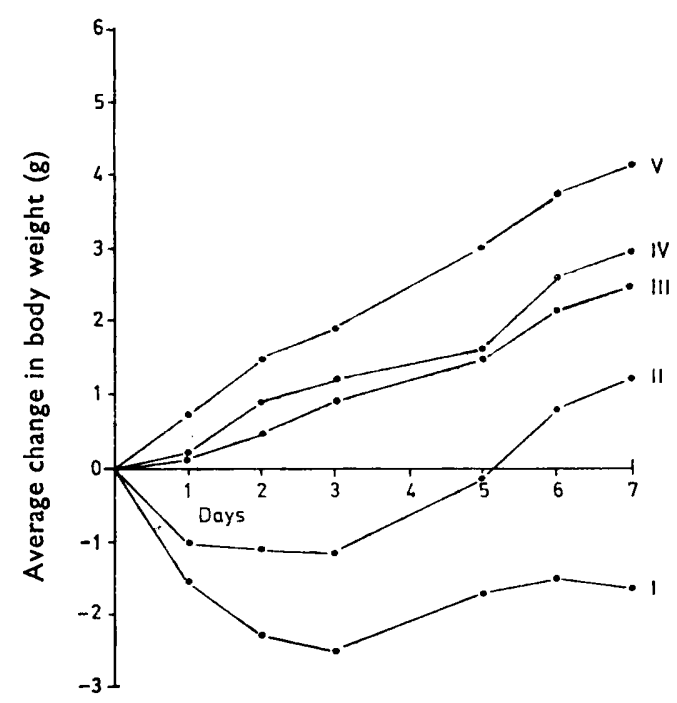

FIG. 2.-The average change in body weight of groups of five mice given graded doses of $B$. pertussis toxic fraction D-30-I intravenously. Groups of five mice were given a dose of 0.50 (I), 0.25 (II), 0.12 (III), or $0.06 \mu \mathrm{g}$ (IV); a control group (V) received saline.

loss of mouse spleen weight and body weight that we observed with unheated preparations. 


\section{Serological neutralisation of the lienotoxic effect}

It was necessary to administer $0 \cdot 1 \mathrm{ml}$ of undiluted antitoxic serum within $4 \mathrm{hr}$ after the intravenous injection of about 2 LTD50 $(1 \mu \mathrm{g})$ of the sonicate to prevent a 50 per cent. reduction in spleen weight. The results summarised in table IV indicate that an irreversible pathological process in the mouse spleen begins very early after intravenous injection of sonicate or toxin.

TABLE IV

The protective effect of $B$. pertussis " antitoxin" on the lienotoxic effect of $B$. pertussis sonicate in mice

\begin{tabular}{|c|c|c|c|c|}
\hline \multirow{2}{*}{ Treatment } & \multirow{2}{*}{$\begin{array}{l}\text { Time-interval } \\
\text { after challenge } \\
(\mathrm{hr}) \text { at which } \\
\text { antitoxin given }\end{array}$} & \multicolumn{3}{|c|}{$\begin{array}{l}\text { Results for mean spleen weight index* }(\mathrm{mg}) \text { (with percentage } \\
\text { spleen weight }{ }^{\dagger} \text { in brackets) in }\end{array}$} \\
\hline & & expt 1 & expt 2 & expt 3 \\
\hline $\begin{array}{l}\text { Toxin } \ddagger \\
\text { followed by } \\
\text { antitoxin }\end{array}$ & $\begin{array}{r}1 \\
2 \\
4 \\
6 \\
8 \\
12 \\
24\end{array}$ & $\begin{array}{c}\ldots \\
\ldots \\
\cdots \\
27(45) \\
\dddot{132)} \\
21(35)\end{array}$ & $\begin{array}{l}44(73) \\
31(52) \\
27(43) \\
28(45) \\
17(28) \\
33(54)\end{array}$ & $\begin{array}{c}52(87) \\
48(81) \\
34(57) \\
\ldots \\
23(39) \\
26(43) \\
21(36)\end{array}$ \\
\hline Toxin only & $\ldots$ & $17(28)$ & $19(32)$ & $18(30)$ \\
\hline None & $\ldots$ & $60(100)$ & $61(100)$ & $59(100)$ \\
\hline
\end{tabular}

* Mean spleen weight per $10 \mathrm{~g}$ body weight of five test mice.

† Percentage of mean spleen weight in relation to that of five normal control mice.

$\ddagger$ Each of a group of five mice was given $1 \mu \mathrm{g}$ sonicate intravenously, and, after the stated time, $0.1 \mathrm{ml}$ of undiluted antitoxin intravenously; 7 days later the mean spleen weight per $10 \mathrm{~g}$ body weight was determined.

\section{Histological findings}

On the 7th day after intravenous injection of a relatively high sublethal dose, $0 \cdot 15 \mu \mathrm{g}$ of toxin fraction D-23-II, the mouse spleens showing considerable atrophy were grey-yellow or pink in colour. Although subcutaneous administration of cortisone acetate to mice also produced a decrease in their spleen weights (table V), the colour of the organ remained normal in this case.

The spleens of toxin-treated mice show fibrosis, loss of follicles and accumulation of lymphocytes in the lymphatic sinuses (fig. 3). In the spleens of mice treated with $5 \mathrm{mg}$ of cortisone acetate, however, the normal structure is well preserved, though the follicles are reduced in size.

In order to examine the early pathological changes, groups of four mice were killed successively at 1, 2, 4, 8 and $12 \mathrm{hr}$, and 1, 2, 3, 5 and 7 days after intravenous injection of the toxin.

At $4 \mathrm{hr}$ after injection of the toxin, hyperaemia and oedema are evident in 


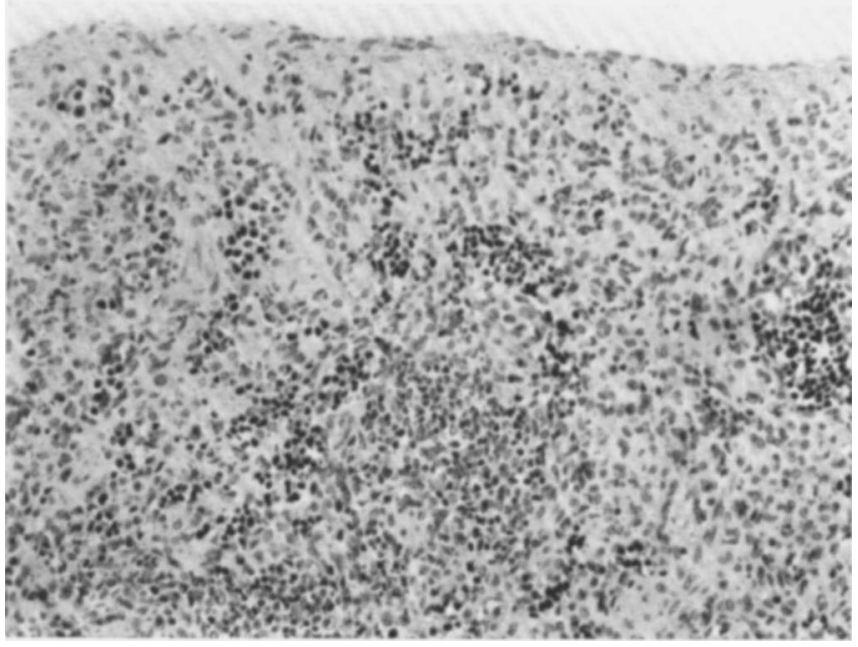

Fig. 3.-Mouse spleen. Reduction in lymphocytes and generalised splenic atrophy 7 days after intravenous injection of $B$. pertussis toxin. There is pronounced fibrosis with loss of follicles and there are accumulations of lymphocytes in the sinuses. Haematoxylin and eosin (HE). $\times 150$.
FIG. 4.-Spleen. Perifollicular hyperaemia and peripheral migration of lymphocytes $4 \mathrm{hr}$ after intravenous injection of toxin. HE. $\times 120$.

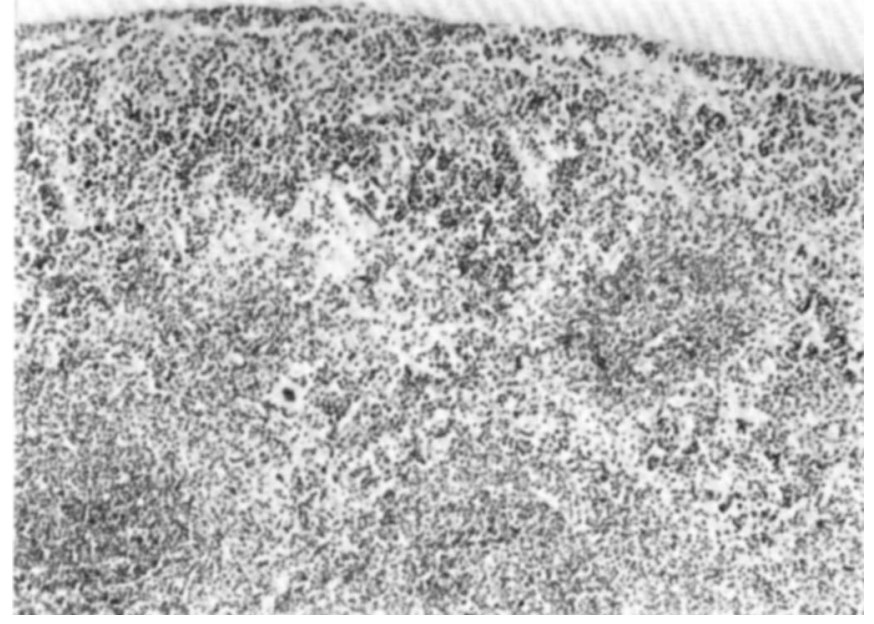

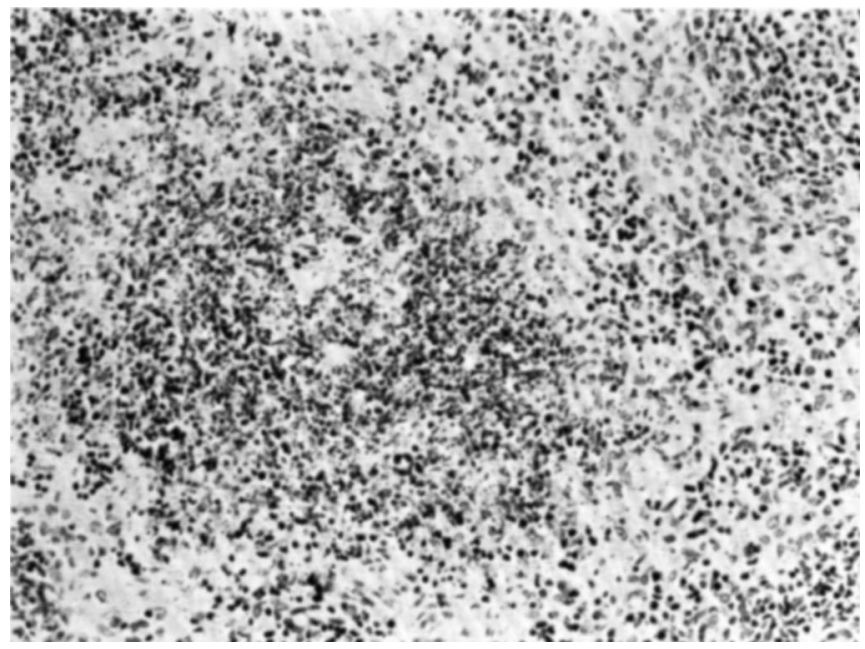

Fig. 5.-Spleen 2 days after intravenous injection of toxin. Necrosis of a follicle. HE. $\times 220$. 


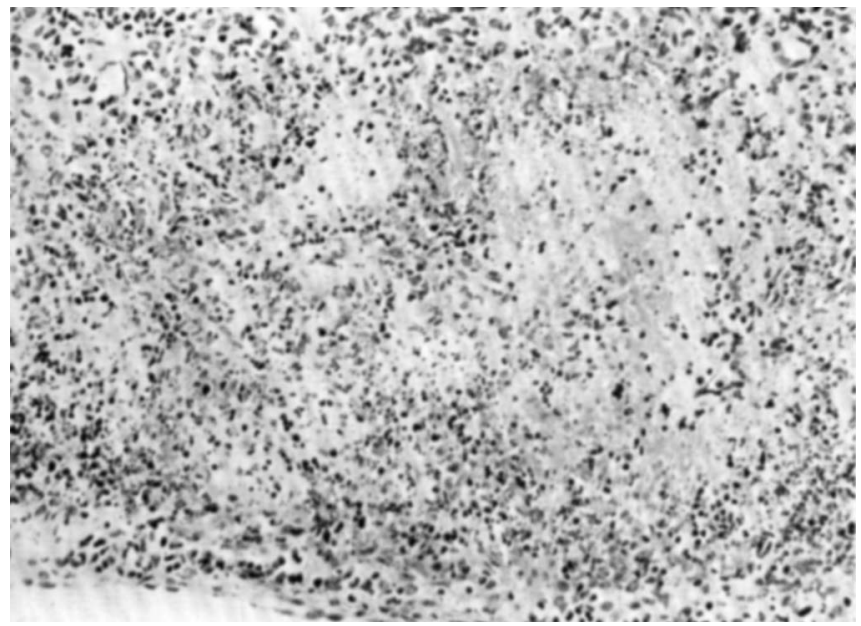

FIG. 6.-Spleen. Replacement of necrotic foci by fibrosis 3 days after intravenous injection of toxin. HE. $\times 170$.

FIG. 7.-Fibroblastic proliferation around a necrotic focus in mouse spleen 5 days after intravenous injection of toxin. HE. $\times 150$.

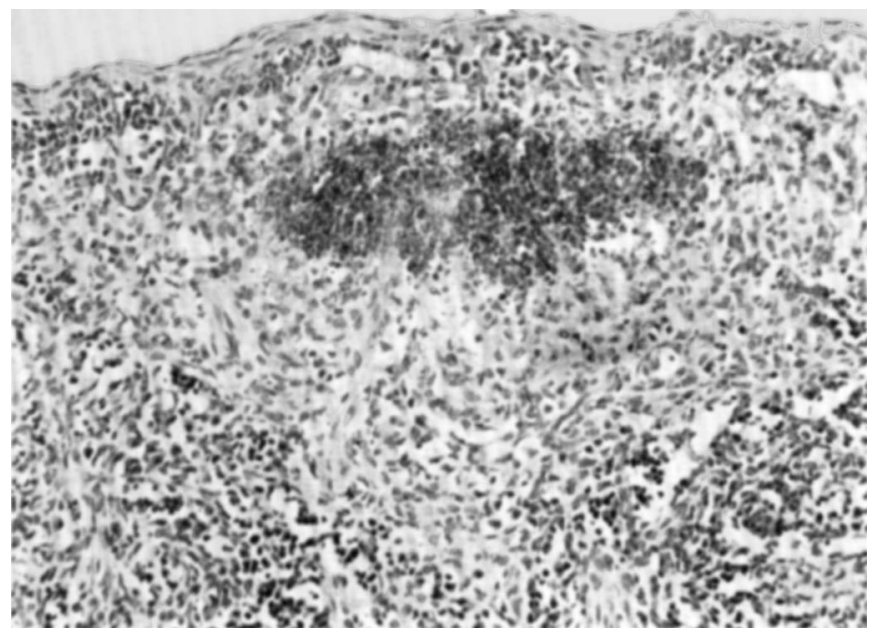

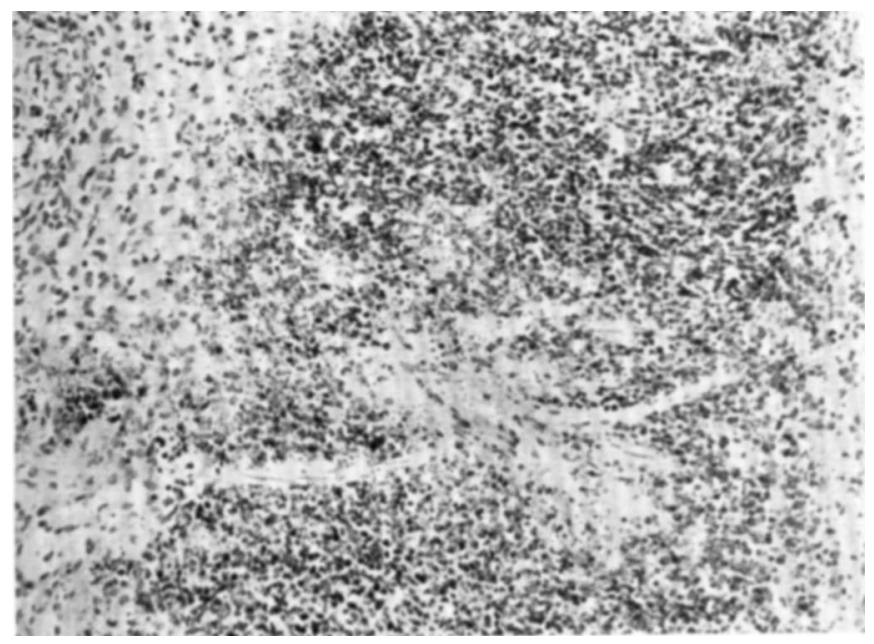

FIG. 8.-Fibrosis and widespread necrosis of spleen 5 days after intravenous injection of toxin. HE. $\times 150$. 
the perifollicular areas, and there are peripheral groups of 10-15 lymphocytes in the spleen. The appearances indicate that there is migration of lymphocytes into the circulation (fig. 4).

At $8 \mathrm{hr}$, hyperaemia has subsided and some follicles are becoming indistinct. Fibrotic changes are not yet evident. Lymphocytes, megakaryocytes and reticular cells are present in the relatively large splenic veins.

TABLE V

The effect of a graded subcutaneous dose of cortisone on mouse spleen weight recorded 7 days later*

\begin{tabular}{l|c|c}
\hline $\begin{array}{c}\text { Dose of } \\
\text { cortisone } \\
(\mathrm{mg})\end{array}$ & $\begin{array}{c}\text { Body weight } \\
\text { change } \\
(\mathrm{g})\end{array}$ & $\begin{array}{c}\text { Spleen weight per } \\
10 \mathrm{~g} \text { body weight } \\
\text { (mg) }\end{array}$ \\
\hline 0 & +4.5 & 63 \\
0.63 & $+1 \cdot 3$ & 46 \\
1.25 & -0.8 & 47 \\
2.50 & -1.3 & 35 \\
5.00 & -0.8 & 18 \\
& & \\
5.0 & -2.5 & 14 \\
5.0 & -3.5 & 23 \\
5.0 & -0.4 & 38 \\
5.0 & -1.8 & 22 \\
5.0 & -1.5 & 36 \\
& & \\
0 & +2.7 & 71 \\
0 & +5.2 & 58 \\
0 & +5.4 & 60 \\
0 & +4.5 & 87 \\
0 & +5.3 & 66 \\
\hline
\end{tabular}

* A graded dose of cortisone acetate was injected subcutaneously into groups of mice. The animals were killed 7 days after the injection and the spleen weight and body weight changes were estimated.

At $12 \mathrm{hr}$, there is cellular degeneration; nuclear debris is present among the lymphocytes and in some areas near the splenic capsule. The perifollicular area shows slight fibrosis. The lymphocytes throughout the spleen are reduced in number.

On day 1, many necrotic foci are distributed around the red pulp and fibrosis is now marked. Most of the follicles are irregular in size and some show a loose structure or frankly necrotic degeneration. Splenocytes are present in the large splenic veins.

On day 2, necrotic foci in the red pulp now coalesce and extend, and fibrosis is also extensive. The spleen is generally atrophic and the changes become more intensified on day 3 with replacement of necrotic foci by fibrosis (figs. 5 and 6).

On day 5, the necrotic foci and disintegrating follicles are reduced in number and there is further replacement by fibrosis (figs. 7 and 8 ).

On day 7 , the atrophy continues with increased general fibrosis of the spleen. Lymphocytes are virtually absent, but an occasional group may be seen. 
The pathological changes described above occurred earlier and were more intensive when $0.3 \mu \mathrm{g}$ of the toxin was given. The results of our studies of the morphological changes observed in other organs will be described elsewhere.

\section{Changes in the peripheral blood of the test mice}

Within 1 day after intravenous injection of $0.25 \mu \mathrm{g}$ of toxin, a marked leucocytosis was observed, but there was no absolute lymphocytosis. The effect produced by a $1-\mu \mathrm{g}$ dose of the sonicate was almost identical; this activity of the sonicate appeared to be unaffected by heating at $56^{\circ} \mathrm{C}$ for $10 \mathrm{~min}$., although its lienotoxic activity was then lost (fig. 9).

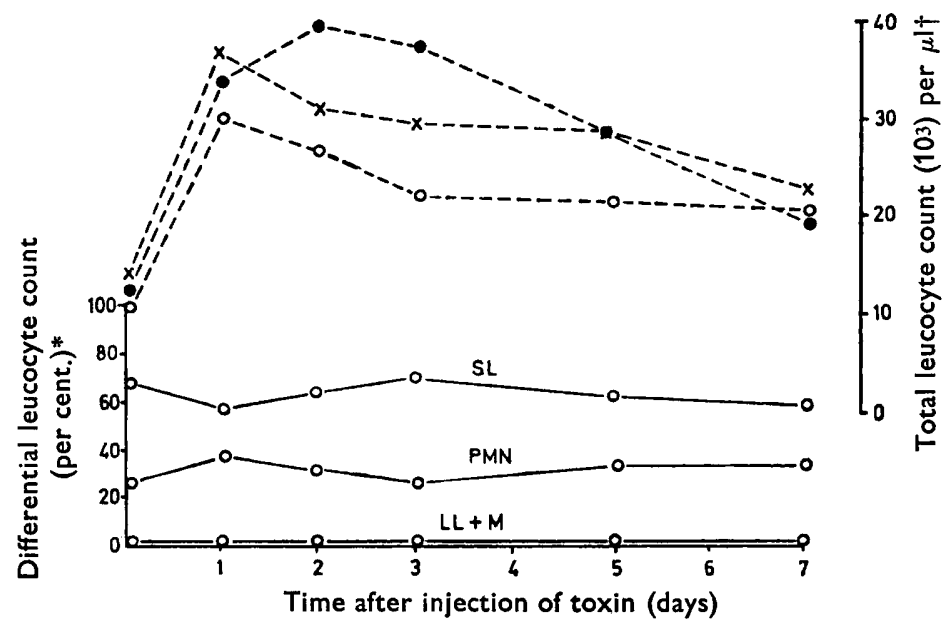

Fig. 9.-Leucocyte responses of mice after intravenous injection of $\boldsymbol{B}$. pertussis toxin.

* Differential leucocyte count (per cent.): PMN (polymorphonuclear leucocytes), SL (small lymphocytes), LL (large lymphocytes) and $\mathrm{M}$ (monocytes) in mice given $0.25 \mu \mathrm{g}$ of toxic fraction D-30-I intravenously.

$\dagger$ Total leucocyte counts after (i) $0---0=0.25 \mu \mathrm{g}$ toxic fraction D-30-I; (ii) $\times---\times$ $=1 \mu \mathrm{g}$ sonicate; and (iii) $\bullet--\bullet=50 \mu \mathrm{g}$ sonicate heated at $56^{\circ} \mathrm{C}$ for $10 \mathrm{~min}$.

\section{Discussion}

When single sublethal doses of partially purified thermolabile toxin of Bordetella pertussis phase- 1 organisms are injected intravenously into mice, the spleens of the test animals show marked atrophy and develop a grey-yellow colour within 7 days. A similar reduction in spleen size was observed in mice given cortisone acetate subcutaneously, but there was little change in spleen colour in these mice. The toxin-induced decrease in spleen weight was shown to be proportional to the dose of toxin injected, within the range 0.01 to $1.0 \mu \mathrm{g}$ protein of a semi-purified preparation of toxin. A similar but less marked toxic effect was produced by the sonicate from which the toxin was fractionated, and the factor concerned was inactivated almost completely by exposure to heat at $56^{\circ} \mathrm{C}$ for $10 \mathrm{~min}$.

The characteristic lymphocytotoxic effect of adrenal corticotrophic steroid hormones has been well documented since the first report by Dougherty and 
White (1945). In the present study, a decrease in spleen size or weight and a diminution in the number of small lymphocytes and in the size of follicles were evident in the spleen of mice subcutaneously treated once with cortisone acetate and killed 7 days later, but in this case the normal histological structure was well preserved. After intravenous injection of the toxin, however, the histology of the spleen became markedly abnormal. In our experiments, the observed pathological changes predominantly involved the spleen rather than the other organs and tissues; this suggests that $B$. pertussis or its thermolabile toxin may be selectively toxic for splenic tissue. We have coined the term lienotoxicity for this toxic phenomenon. Ehrich et al (1942) reported that an ultrasonicated extract of $B$. pertussis caused necrosis in the rabbit spleen and an increase in its weight as a result of hyperaemia when it was administered intravenously. Kurokochi (1961) reported that within 18 and $48 \mathrm{hr}$ after intraperitoneal injection of his purified $B$. pertussis toxin into mice, there was a varied degree of splenitis associated with oedema, proliferation in follicles and focal necrosis. Presumably, if responses to a sublethal dose of the toxin had been studied over a longer period, morphological changes similar to those observed in our experiments might have been obtained.

Since the first report by Morse (1964), on the other hand, the lymphocytosis experimentally induced in mice has been studied as one of the notable biological activities of $B$. pertussis organisms (Morse, 1965, 1966; Morse and Riester, 1967 $a$ and $b$; Ishida, 1968; Iwasa et al., 1968) and attempts to isolate the active component have been made by Iwasa et al. (1968) and by Morse and Bray (1969). With reference to the present study it seems noteworthy that the active substance is less active in dermonecrosis tests and more stable to heat at $56^{\circ} \mathrm{C}$ than the thermolabile toxin (Iwasa et al., 1968; Morse and Bray), and, after intravenous or intraperitoneal injection into mice, induces splenic atrophy and loss of body weight at a later period (Iwasa et al., 1966; Ishida). However, Morse (1965) reported a decrease in the population of splenic lymphocytes, disruption of splenic structure, increased spleen weight and absence of focal necrosis in spleens of mice associated with a lymphocytic response on the 4th day after the animals received $B$. pertussis vaccine. If these changes in the spleen were caused by some bacterial component(s) having lymphocytosispromoting activity, some changes in the peripheral lymphocytes should be noticed in mice given the thermolabile toxin intravenously. Although a leucocytosis was observed in these mice, there was no absolute lymphocytosis. The effect produced by a sonicated preparation was almost identical, but it appeared that the factor involved was not inactivated by heat at $56^{\circ} \mathrm{C}$ for $10 \mathrm{~min}$. Similar changes in the peripheral blood were produced in mice given an intravenous injection of either live or merthiolate-killed whole organisms of the Tohama strain grown in liquid or solid culture medium (unpublished data).

These results still seem to be conflicting and await more extensive investigations with more purified thermolabile toxin. In addition, other factors inherent in the strains of $B$. pertussis phase-1 organisms and in the mice used might be of importance. 


\section{SUMMARY}

A highly toxic fraction causing dermonecrosis in guinea-pigs and a lethal effect in mice was obtained from Bordetella pertussis phase-1 organisms. Intravenous injection of this toxic fraction into mice produced a considerable reduction in spleen weight within 7 days. The histological findings indicate that $B$. pertussis causes an atrophy of the spleen. The term "lienotoxicity" is proposed to designate this toxic phenomenon. Whether dermonecrosis, lethality and lienotoxicity are caused by three different agents contained in the preparation studied has not been determined.

The authors wish to thank Miss Yoko Ajiki for her conscientious assistance.

\section{REFERENCES}

ANDERSEN, ElSE K. 1957. Studies on the occurrence of lung oedema in mice after intranasal H. pertussis inoculation. Acta path. microbiol. scand., 40, 248.

BRADFORD, W. L. 1938. Experimental infection in the mouse produced by intratracheal inoculation with Hemophilus pertussis. Amer. J. Path., 14, 377.

Burnet, F. M., AND TImmins, Cecily 1937. Experimental infection with Haemophilus pertussis in the mouse by intranasal inoculation. Br. J. Exp. Path., 18, 83.

DOUGHERTY, T. F., AND WHITE, A. 1945. Functional alterations in lymphoid tissue induced by adrenal cortical secretion. Amer. J. Anat., 77, 81.

Ehrich, W. E., Bondi, A., JR, Mudd, S., AND Flosdorf, E. W. 1942. The tolerance of rabbits for the agglutinogen and the toxins of Hemophilus pertussis. Amer.J. Med. Sci., 204, 530.

IsHIDA, S. 1968. Characterization of the body weight-decreasing toxicities in mice by the lymphocytosis-promoting factor and the heat-labile toxin of $B$. pertussis and endotoxin. Jap. J. Med. Sci. Biol., 21, 115.

Iwasa, S., Asakawa, S., Ishida, S., AND Kurokawa, M. 1966. The study on lymphocytosispromoting factor produced by Bordetella pertussis. Jap. J. Bact., 22, 233 (in Japanese).

Iwasa, S., Ishida, S., Asakawa, S., AND Kurokawa, M. 1968. Lymphocytosis-promoting factor produced by Bordetella pertussis. Partial purification and characterization. Jap. J. Med. Sci. Biol., 21, 363.

KuroKochI, T. 1961. Studies on pertussal toxin. VIII. The histopathological studies on each organ of mice inoculated with pertussal toxin. Jap. J. Bact., 16, 1046 (in Japanese).

MeIster, A. 1952. Crystalline lactate dehydrogenase. In Biochemical preparations, ed. by E. G. Ball, New York, vol. 2, p. 18.

Morse, S. I. 1964. Studies on the leukocytosis induced by Bordetella pertussis. J. Pediat., 65, 1019.

MoRse, S. I. 1965. Studies on the lymphocytosis induced in mice by Bordetella pertussis. J. Exp. Med., 121, 49.

MORSE, S. I. 1966. The effect of hydrocortisone and X-irradiation on the lymphocytosis induced by Bordetella pertussis. J. Exp. Med., 123, 283.

Morse, S. I., AND BraY, Karen K. 1969. The occurrence and properties of leukocytosis and lymphocytosis-stimulating material in the supernatant fluids of Bordetella pertussis cultures. J. Exp. Med., 129, 523.

Morse, S. I., AND RIESTER, SALLIE K. 1967a. Studies on the leukocytosis and lymphocytosis induced by Bordetella pertussis. I. Radioautographic analysis of the circulating cells in mice undergoing pertussis-induced hyperleukocytosis. J. Exp. Med., 125, 401.

Morse, S. I., AND Riester, SAllie K. 1967b. Studies on the leukocytosis and lymphocytosis induced by Bordetella pertussis. II. The effect of pertussis vaccine on the thoracic duct lymph and lymphocytes of mice. J. Exp. Med., 125, 619. 
Onoue, K., Kitagawa, M., AND Yamamura, Y. 1963. Chemical studies on cellular components of Bordetella pertussis. III. Isolation of highly potent toxin from Bordetella pertussis. J. Bact., 86, 648.

SAto, M. 1958. Studies on the fractionation of Haemophilus pertussis antitoxin. Jap. J. Microbiol., 2, 279.

SAto, M., TenJin, H., AND IIDA, T. 1958. Fractionation of Haemophilus pertussis antiserum proteins. Jap. J. Microbiol., $2,309$.

TAGUCHI, M. 1958. Studies on a variant of Bordetella pertussis. Jap. J. Bact., 13, 966 (in Japanese).

Yamamoto, A., Irda, T., Komatsu, N., Ogata, S., Komase, Y., SAto, M., and Yoshida, T. 1959. Studies on the pertussal toxin. II. Nisshin Igaku, 46, 384 (in Japanese). 